\title{
Soil and foliar nitrogen and boron fertilization of almond trees grown under rainfed conditions
}

\author{
Margarida Arrobas*, António Ribeiro, David Barreales, Ermelinda L. Pereira*, \\ M. Ângelo Rodrigues \\ Centro de Investigação de Montanha (CIMO), Instituto Politécnico de Bragança, Campus de Santa Apolónia, 5300-253 Bragança, Portugal
}

\section{A R T I C L E I N F O}

\section{Keywords:}

Prunus dulcis

Almond yield

Rainfed agriculture

Sufficiency ranges

Nutrient removal

\begin{abstract}
A B S T R A C T
Rainfed orchards have huge social importance in territories of low agro ecological potential. Research on almond is limited for dry-farmed orchards in particular for crop nutrition and fertilization. This makes difficult to implement a cropping practice adjusted to the ecological constraints of these agrosystems. It is known that nitrogen (N) and boron (B) are determining nutrients for dicot tree crops such as olive and vineyards grown under these environmental conditions. Thus, this study aims to test at what level the crop responds to soil-applied $\mathrm{N}$ and $\mathrm{B}$, and whether the foliar sprays can supplement or replace the application of the nutrients to the soil. It is also important to check if the sufficiency ranges set for the almond, which have been based on irrigated orchards, are adjusted for rainfed farming. The $\mathrm{N}$ rates applied to the soil were 0 (N0), 25 (N25), 50 (N50) and 100 (N100) kg $\mathrm{hm}^{-2}$ and those of B 0 (B0), 1 (B1), 2 (B2) and 3 (B3) $\mathrm{kg} \mathrm{hm}^{-2}$. The foliar sprays consisted of three annual applications of $N$ (two in 2017) and two applications of B (one in 2017), the last ones of 2015 and 2016 applied at post-harvest. Foliar N and B sprays were respectively applied at the concentrations of $0.5 \% \mathrm{~N}$ and $0.036 \% \mathrm{~B}$. The experiment was arranged as a split-plot design with soil applied N or B assigned to the main plots and foliar $\mathrm{N}$ or B as subplots. Kernel yield showed a marked alternate-fruiting, with two years of good crops (2015 and 2017) and a year of practically no production (2016), likely due to adverse ecological conditions for almond growth and cropping practices incorrectly performed. Soil-applied N significantly increased kernel yield in comparison to the control but the differences were not significant in $\mathrm{N}$ rates higher than $25 \mathrm{~kg} \mathrm{~N} \mathrm{hm}^{-2}$. The application of B to the soil improved tissue B concentrations but did not increase productivity. In general, foliar applications of $\mathrm{N}$ or B failed to improve plant nutritional status and kernel yield. The current sufficiency ranges for almond seem to be unnecessarily narrow for several nutrients such as $\mathrm{N}$, potassium (K), calcium (Ca), manganese $(\mathrm{Mn})$ and iron (Fe), since several results were found to be out of the sufficiency range with no apparent negative consequences for the trees. The laboratories carrying out soil testing and plant analysis should take this into account in diagnosing the nutritional status of almond orchards.
\end{abstract}

\section{Introduction}

The almond tree (Prunus dulcis [Miller] Webb) plays a major socioeconomic role in the agriculture of countries benefiting from a Mediterranean type climate, such as in Southern Europe or North Africa. The almond tree is a hardy crop that evolved in the dry and semi-arid territories of the Caucasus and nearby regions to the north of the Fertile Crescent. It was, for centuries, the last option for the agricultural use of marginal lands in regions of dry to semi-arid climate, where rains were concentrated in the cold season (Aguiar and Pereira, 2017). However, productivity is poor in semi-arid Mediterranean ecosystems if crops are rainfed grown (Almagro et al., 2016). According to the national statistics of Southern European and North African countries, where the acreage of rainfed managed orchards dominate over the irrigated ones (for instance, Portugal, Spain, Morocco and Tunisia), the yield is very low, varying between 300 and 700 (almond with shell) $\mathrm{kg} \mathrm{hm}^{-2}$ (FAO, 2018). These low yield levels of dry-farmed orchards have contributed to its progressive abandonment.

In the last few years the price of almond has increased and there seems to be a renewed interest in the crop in the Mediterranean basin. The crop is being established in intensive irrigated systems, but also under rainfed conditions on poor fertility soils where herbaceous

\footnotetext{
* Corresponding authors.

E-mail addresses: marrobas@ipb.pt (M. Arrobas), antrib@ipb.pt (A. Ribeiro), davidsantos@ipb.pt (D. Barreales), epereira@ipb.pt (E.L. Pereira), angelor@ipb.pt (M.Â. Rodrigues).
} 
agriculture is not profitable. The low-intensive managed orchards are playing an interesting socio-economic role. They are being planted by some professional farmers, but also by several other landowners, employed in other sectors of the economy, which manage their farms during the weekend, days-off or holidays, allowing them to increase household annual income. This type of agriculture is in line with the European development strategy (EC, 2010) where it seeks to foster a high-employment economy delivering social and territorial cohesion.

However, to achieve sustainability in this new wave of rainfed plantations, cropping practices must be adjusted to the agroecological constraints of the ecosystem and production costs must be reduced. Crop fertilization is an aspect that should be taken into account, since it helps to regulate crop productivity, but excessive fertilization may lead to environmental pollution. Most of the previous studies on almond fertilization have been carried out under irrigated conditions (Nyomora and Brown, 1999; Saa et al., 2014, 2017; Muhammad et al., 2015) and these data may be of little use in rainfed-managed orchards. Almond cultivated under irrigated conditions can respond to $\mathrm{N}$ rates above $300 \mathrm{~kg} \mathrm{~N} \mathrm{hm}^{-2}$ (Muhammad et al., 2015), but these values can be fiveto-ten times higher than those advised for rainfed managed orchards (LQARS, 2006; Arquero and Serrano, 2013). Furthermore, excessive N rates should be avoided since they can promote environmental pollution (Werner, 2007; Havlin et al., 2014) and, in the particular case of almond, to the increased incidence of hull rot, caused by Rhizopus stolonifer (Saa et al., 2016).

Under rainfed conditions, application of fertilizers is restricted to late winter or early spring following the rainy season. After mid-spring to late summer, the lack of rain prevents the efficient use of fertilizers applied to the soil. In these conditions, foliar sprays could be a complemental strategy to improve the nutritional status of trees, since previous studies on irrigated almond have shown that foliar sprays applied at post-harvest can enhance flowering in the following spring (Nyomora and Brown, 1999; Saa et al., 2017). N and B deficiencies are two major nutritional disorders affecting tree crop growth and yield, as reported from other important tree crop species grown across the Mediterranean basin, such as olive (Arrobas et al., 2010; Rodrigues et al., 2011), chestnut (Arrobas et al., 2017, 2018) and pistachio (Weinbaum et al., 1994; Güneş et al., 2010). Thus, the objective of this work was to evaluate the almond tree response to the application of $\mathrm{N}$ or B to the soil with and without supplementation of foliar N or B sprays under rainfed conditions. The working hypotheses are that rainfedmanaged almond could respond to the application of $\mathrm{N}$ or B to the soil and foliar applications are an important addition to soil fertilization. It is also an objective of this work to assess if the sufficiency ranges established for the almond tree, based mainly on data gathered from irrigated orchards, can be used in rainfed orchards.

\section{Material and methods}

\subsection{Site characterization}

The field trials were established in a 12-year-old rainfed managed commercial almond orchard, located near Alfândega da Fé (lat. $41^{\circ} 21^{\prime}$; long. $6^{\circ}$ 57'; $576 \mathrm{~m}$ asl) NE Portugal. The region benefits from a Mediterranean climate, typically with two main seasons, the winter, characterized by low temperatures and relatively high precipitation, and a hot and dry summer. Average monthly air temperatures and accumulated monthly rainfall for the three-year trial are presented in Fig. 1. Fig. 2 shows detailed data of daily rainfall records for the flowering and fruit set period of 2016, since this data will be related to the failure of crop in 2016. The experimental plot has a slight slope (less than 2\%) and the soil is a loamy textured dystric Regosol (WRB, 2015). Some selected soil properties determined shortly before the trial started from three composite (10 replicates) soil samples randomly collected at 0-20 cm depth, are shown in Table 1.

\subsection{Experimental design and crop management}

The orchard was planted with the cultivar Masbovera (75\% of the trees) interplanted with 'Glorieta' (pollinator), arranged in continuous rows at the ratio of 3:1. Both cultivars were grafted on GF-777 rootstock. The trees were planted at a density of 416 trees $\mathrm{hm}^{-2}(6 \times 4 \mathrm{~m})$. The $\mathrm{N}$ fertilization trial was installed on 'Masbovera' and the $\mathrm{B}$ trial on 'Glorieta'. The fertilizer treatments and the replications (blocks) were set along the rows with an untreated tree between plots. $\mathrm{N}$ and $\mathrm{B}$ were applied to the soil late in March, shortly after bloom, at four rates. N rates were 0 (N0), 25 (N25), 50 (N50) and 100 (N100) $\mathrm{kg} \mathrm{hm}^{-2}$ applied as ammonium nitrate $(20.5 \% \mathrm{~N}$ ) and $\mathrm{B}$ rates 0 (B0), 1 (B1), 2 (B2) and 3 (B3) $\mathrm{kg} \mathrm{hm}^{-2}$ applied as borax pentahydrate $\left(\mathrm{Na}_{2} \mathrm{~B}_{4} \mathrm{O}_{7} \cdot 5 \mathrm{H}_{2} \mathrm{O}\right)(15 \% \mathrm{~B})$. The fertilizer treatments of soil-applied nutrients comprised two rows of trees per nutrient separated by rows of untreated trees, in which half of the rows received additional foliar sprays of $\mathrm{N}$ and $\mathrm{B}$. Foliar $\mathrm{N}$ was applied three times $\left[5 \mathrm{~g} \mathrm{~L}^{-1} \mathrm{~N}\right.$ as urea $(46 \% \mathrm{~N}), 4.4 \mathrm{~L}$ water tree ${ }^{-1}$ ] and $\mathrm{B}$ twice $\left(0.36 \mathrm{~g} \mathrm{~L}^{-1} \mathrm{~B}\right.$ as borax pentahydrate, $\left.15 \% \mathrm{~B}\right)$ during the three growing seasons (only twice and once in 2017, respectively for N and B, since an application was at post-harvest and the trial ended after the third harvest). This means the application consisted of $\sim 27 \mathrm{~kg} \mathrm{~N} \mathrm{hm}^{-2}$ in 2015 and 2016 (three applications) and $18 \mathrm{~kg} \mathrm{~N} \mathrm{hm}^{-2}$ in 2017, and $1.4 \mathrm{~kg} \mathrm{~B} \mathrm{hm}^{-2}$ in 2015 and 2016 and $0.7 \mathrm{~kg} \mathrm{~B} \mathrm{hm}^{-2}$ in 2017. The experiments were arranged as a split-plot design. The nutrients applied to the soil were assigned to main plots in a randomized complete block design with three replications. The set of foliar applications of $\mathrm{N}$ or $\mathrm{B}$ were assigned to subplots within each main plot. The treatments of foliar applied N were NF0 (N applied to the soil only) and NF3 (soil plus foliar N applied three times) and the treatments of B were BF0 (B applied to the soil) and BF2 (soil plus foliar B applied twice). Each experimental unit consisted of groups of three similar trees. Thus, the experiments of $\mathrm{N}$ and $\mathrm{B}$ consisted of 24 plots each ( 4 main plots, divided into two subplots and three blocks as replicates) of three trees.

$\mathrm{N}$ and $\mathrm{B}$ included in the experimental designs, and a supplement of phosphorus (P) $\left(50 \mathrm{~kg} \mathrm{P}_{2} \mathrm{O}_{5} \mathrm{hm}^{-2}\right)$ and $\mathrm{K}\left(50 \mathrm{~kg} \mathrm{~K}_{2} \mathrm{O} \mathrm{hm}{ }^{-2}\right)$ added in similar rates to all plots, were applied in late March, on 23rd, 30th, and 29th in 2015, 2016 and 2017, respectively. Foliar sprays were applied on May 27th (N and B), July 6th (N) and August 31st (N and B) in 2015, June 03rd (N and B), July 21st (N) and September 14th (N and B) in 2016 and May 24th (N and B) and July 19th (N) in 2017. The last foliar applications, in 2015 and 2016, were performed after harvest. The orchard floor was managed with a natural cover mowed once a year in mid-April with tree rows maintained with a glyphosate-based herbicide. The farmer pruned the trees every three years supplemented with annual light pruning. During the experimental period, the trees were subjected to the most severe triennial pruning in January 2016, having received only light pruning in 2015 and 2017. During the three-year trial the orchard did not receive any phytosanitary treatment.

\subsection{Tissue sampling, harvest and analytical procedures}

Leaf samples were taken during the growing seasons, just prior to each foliar fertilization event. Leaves were collected following the standard procedure for almond (Bryson et al., 2014). Young leaves were collected with fully expanded blades positioned in non-fruiting spurs in the four quadrants. The samples were oven-dried at $60^{\circ} \mathrm{C}$ and ground. Tissue analyses were performed by Kjeldahl $(\mathrm{N})$, colorimetry, after burned with $\mathrm{CaO}$ at $500{ }^{\circ} \mathrm{C}$ during $90 \mathrm{~min}$. (B), colorimetry (P), flame emission spectrometry $(\mathrm{K})$ and atomic absorption spectrophotometry ( $\mathrm{Ca}, \mathrm{Mg}, \mathrm{Cu}, \mathrm{Fe}, \mathrm{Zn}$ and $\mathrm{Mn}$ ) after microwave digestion. In 2016 and 2017, flower samples (130 flowers per experimental unit) were also taken at full bloom for elemental analysis. Flowers were randomly taken in all quadrants of the tree and subjected to the same treatments and analysis as referred to for the leaves.

In late summer, the fruits were harvested with a trunk shaker, unloaded in a groundsheet and weighed fresh. Subsampling of fresh fruits 


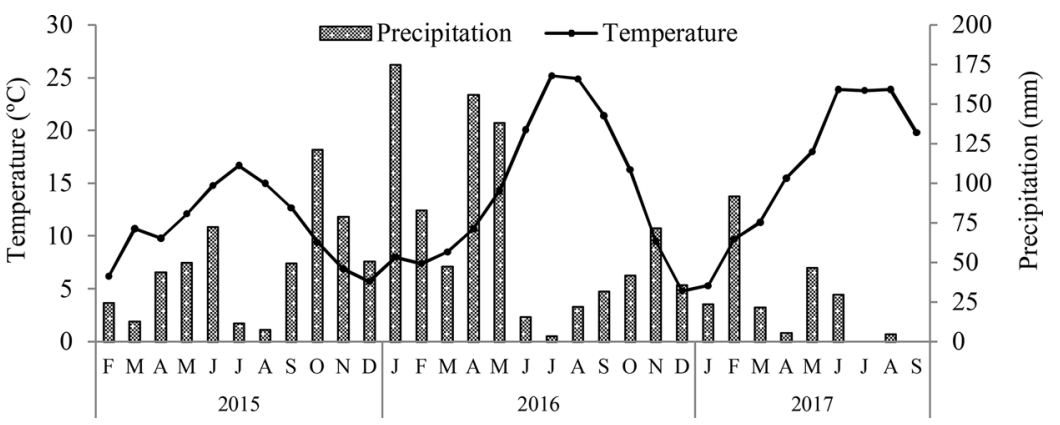

Fig. 1. Average monthly temperatures and accumulated precipitation recorded during the experimental period from an automatic weather station located near the field trials.

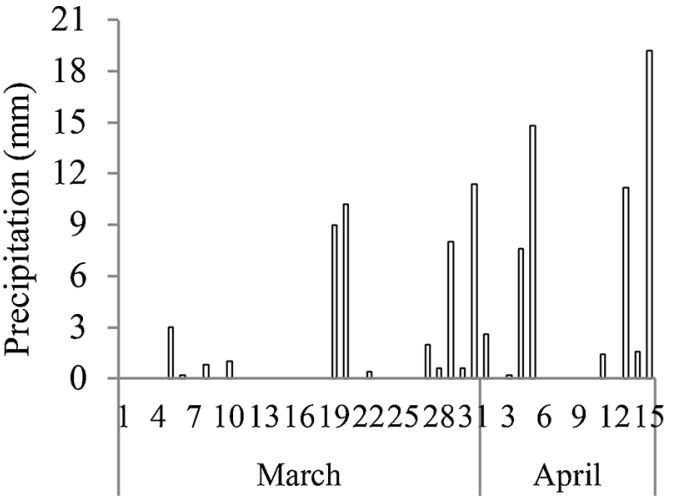

Fig. 2. Daily precipitation recorded in March and early April in 2016 from an automatic weather station located near the field trials.

Table 1

Selected properties of the soil (average \pm standard deviation) sampled shortly before the trials started at a depth of $0-20 \mathrm{~cm}$.

\begin{tabular}{|c|c|}
\hline Soil properties & \\
\hline $\mathrm{pH}_{\mathrm{H} 2 \mathrm{O}}$ & $5.2 \pm 0.06$ \\
\hline $\mathrm{pH}_{\mathrm{KCl}}$ & $4.3 \pm 0.07$ \\
\hline Oxidizable $\mathrm{C}\left(\mathrm{g} \mathrm{kg}^{-1}\right)^{\mathrm{a}}$ & $14.8 \pm 0.42$ \\
\hline Kjeldahl $\mathrm{N}\left(\mathrm{g} \mathrm{kg}^{-1}\right)$ & $1.5 \pm 0.21$ \\
\hline $\mathrm{NO}_{3}{ }^{-}\left(\mathrm{mg} \mathrm{kg}^{-1}\right)^{\mathrm{b}}$ & $55.9 \pm 4.13$ \\
\hline $\mathrm{NH}_{4}^{+}\left(\mathrm{mg} \mathrm{kg}^{-1}\right)^{\mathrm{c}}$ & $36.9 \pm 4.54$ \\
\hline Extract. B $\left(\mathrm{mg} \mathrm{kg}^{-1}\right)^{\mathrm{d}}$ & $1.2 \pm 0.02$ \\
\hline Extract. $\mathrm{K}\left(\mathrm{mg} \mathrm{kg}^{-1}\right)^{\mathrm{e}}$ & $151.4 \pm 11.12$ \\
\hline Extract. $\mathrm{P}\left(\mathrm{mg} \mathrm{kg}^{-1}\right)^{\mathrm{e}}$ & $31.0 \pm 4.54$ \\
\hline Exchang. $\mathrm{Ca}\left(\mathrm{cmol}_{\mathrm{c}} \mathrm{kg}^{-1}\right)^{\mathrm{f}}$ & $3.7 \pm 0.40$ \\
\hline Exchang. $\mathrm{Mg}\left(\mathrm{cmol}_{\mathrm{c}} \mathrm{kg}^{-1}\right)^{\mathrm{f}}$ & $0.8 \pm 0.06$ \\
\hline Exchang. K $\left(\mathrm{cmol}_{\mathrm{c}} \mathrm{kg}^{-1}\right)^{\mathrm{f}}$ & $0.4 \pm 0.02$ \\
\hline Exchang. $\mathrm{Na}\left(\mathrm{cmol}_{\mathrm{c}} \mathrm{kg}^{-1}\right)^{\mathrm{f}}$ & $0.8 \pm 0.28$ \\
\hline Exchang. acidity $\left(\mathrm{cmol}_{\mathrm{c}} \mathrm{kg}^{-1}\right)^{\mathrm{f}}$ & $0.3 \pm 0.07$ \\
\hline Exchang. $\mathrm{Al}\left(\mathrm{cmol}_{\mathrm{c}} \mathrm{kg}^{-1}\right)^{\mathrm{f}}$ & $0.2 \pm 0.07$ \\
\hline CEC $\left(\mathrm{cmol}_{\mathrm{c}} \mathrm{kg}^{-1}\right)^{\mathrm{f}}$ & $6.1 \pm 0.63$ \\
\hline
\end{tabular}

\footnotetext{
${ }^{\text {a }}$ Walkley-Black.

b $2 \mathrm{M} \mathrm{KCl}$, spectrophotometry UV.

c phenate method for ammonia.

${ }^{\mathrm{d}}$ hot-water, azomethine $\mathrm{H}$.

e ammonium-lactate.

f ammonium-acetate, $\mathrm{pH} 7$.
}

was conducted in the laboratory, separated into kernel, shell and hull, weighed fresh, oven-dried at $65^{\circ} \mathrm{C}$ and weighed again. All these tissues were thereafter analyzed for elemental composition after being submitted to the pre-treatments referred to for the leaves.

\subsection{Data analysis}

Data analysis of almond yield and nutrient concentration in plant tissues was carried out using JMP software. Data was analyzed for normality and homogeneity of variances using the Shapiro-Wilk test and Bartlett's test, respectively. In the split-plot design, soil-applied N or B (main plots), foliar-applied N or B (subplots) and interaction (Soilapplied N or B x Foliar-applied N or B) were treated as fixed, and blocks [Soil-applied N or B] as random factors. After ANOVA examination, the means with significant differences $(\alpha<0.05)$ were separated by the Tukey HSD test.

In addition to analyzing the effect of soil-applied $\mathrm{N}$ or B and foliarapplied $\mathrm{N}$ or B on kernel yield for each year, the three years' results were assigned in the model as repeated observations, with soil-applied $\mathrm{N}$ or B as main plots, foliar-applied $\mathrm{N}$ or B as split-plots and years as split-split plots.

\section{Results}

\subsection{Kernel yield}

In the $\mathrm{N}$ fertilization trial, kernel yield was quite high in 2015 and 2017 if it is taken into account that the orchard is rainfed managed. However, the orchard showed a strong alternate-fruiting pattern, since in 2016, the kernel yield was minimal (Fig. 3). $\mathrm{N}$ application to the soil had a significant effect on productivity, with the highest mean kernel yield $\left(524.6 \mathrm{~kg} \mathrm{hm}^{-2}\right)$ being recorded with the application of $100 \mathrm{~kg} \mathrm{~N}$ $\mathrm{hm}^{-2}$ and the lowest mean value $\left(327.0 \mathrm{~kg} \mathrm{hm}^{-2}\right)$ in the control treatment. The application of $\mathrm{N}$ via foliar spray did not significantly increase kernel yield. It should also be noted that there was no significant interaction between soil and leaf $\mathrm{N}$ application and year, which means that the leaf $\mathrm{N}$ application did not increase kernel yield even when applied to the control treatment.

In the B fertilization trial, with cv. Glorieta, kernel yields were of similar magnitude as in the $\mathrm{N}$ trial with 'Masbovera'. The application of B to the soil did not significantly influence the crop in any of the individual years, nor when the years were assigned as repeated

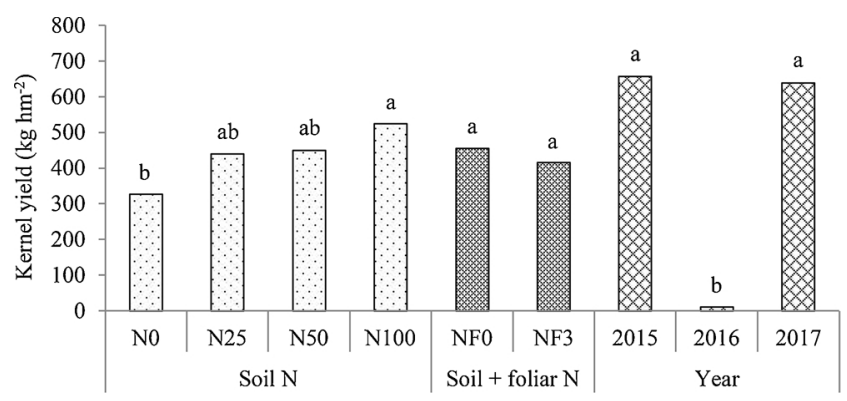

Fig. 3. Kernel yield as a function of $\mathrm{N}$ rate applied to the soil [0 (N0), ..., 100 (N100) $\mathrm{kg} \mathrm{N} \mathrm{hm}^{-2}$ ], to the soil plus foliar spray [NF0 (only soil $\mathrm{N}$ application), $\mathrm{NF} 3$ (soil + three foliar N applications)] and year. Within soil N, soil plus foliar $\mathrm{N}$ or year, means followed by the same letter are not statistically different by Tukey HSD test $(\alpha=0.05)$. 


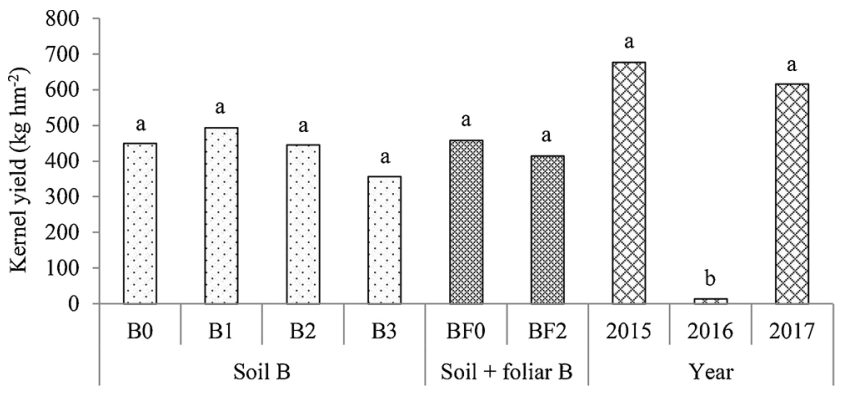

Fig. 4. Kernel yield as a function of B rate applied to the soil [0 (B0), .., 3 (B3) $\mathrm{kg} \mathrm{B} \mathrm{hm}{ }^{-2}$ ], to the soil plus foliar spray [BF0 (only soil B application), BF2 (soil + two foliar B applications)] and year. Within soil B, soil plus foliar B or year, means followed by the same letter are not statistically different by Tukey HSD test $(\alpha=0.05)$.

observations (Fig. 4). The highest B rates displayed even the lowest kernel yields. Foliar B applications also did not significantly influence kernel yield. In 2015 and 2017 the average kernel yields were higher than $600 \mathrm{~kg} \mathrm{hm}^{-2}$ whereas in 2016 were practically nil.

\subsection{Nutrient concentration in plant tissues}

The application of $\mathrm{N}$ to the soil significantly increased leaf $\mathrm{N}$ concentration in five of the eight leaf samplings carried out during the three years of the experiment (Fig. 5). The effect was most evident in the first sampling dates. In 2015, in the first (June) and second (July) sampling dates, leaf $\mathrm{N}$ concentrations were found within the adequate sufficiency range with the average values increasing from the control to the treatments supplying higher amounts of N. In the last sampling date, leaf $\mathrm{N}$ concentrations showed a marked decrease. In 2016, with reduced fruit set and yield, leaf $\mathrm{N}$ concentrations were found above the adequate sufficiency range and on the following dates progressively below. In 2017, leaf $\mathrm{N}$ concentrations were above the adequate sufficiency range on the first date and fell within the adequate sufficiency range on the second date. In general, the application of $\mathrm{N}$ through foliar sprays did not significantly change the concentration of $\mathrm{N}$ in the leaves at any sampling date. There was found significant interaction between soil applied and leaf applied $\mathrm{N}$ only in one of eight sampling dates (Fig. 5).

Leaf B concentration increased significantly as a response to the soil applied B in five of the seven sampling dates, with significant differences occurring in all the dates of 2015 and 2017, but not in the sampling dates of 2016 (Fig. 6). The application of B by foliar spray had only a significant effect on leaf B concentration in one of the seven sampling dates. Significant interaction between soil and foliar B applications was only found once. Leaf B concentrations were found close to and often below the lower limit of the sufficiency range. During the growing season there were not observed appreciable variations in leaf B concentrations.

The application of $\mathrm{N}$ to the soil did not give rise to significant differences or any consistent trend in the concentration of other nutrients ( $\mathrm{P}, \mathrm{K}, \mathrm{Ca}, \mathrm{Mg}, \mathrm{Fe}, \mathrm{Mn}, \mathrm{Cu}$ or $\mathrm{Zn}$ ) in the leaves, and the same was observed with the application of $\mathrm{N}$ as a foliar spray. The application of $\mathrm{B}$ to the soil or through foliar sprays also did not have a significant effect on the concentration of other nutrients in the leaves. Thus, the results of leaf concentrations of $\mathrm{P}, \mathrm{K}, \mathrm{Ca}, \mathrm{Mg}, \mathrm{Fe}, \mathrm{Mn}, \mathrm{Cu}$ and $\mathrm{Zn}$ for all the sampling dates of the three years are presented in Fig. 7 without taking into account the fertilizer treatments of the experimental design.

Leaf $P$ concentration showed a decreasing trend during the growing season. The values were particularly high in the first sampling date of 2016, the year in which almond yield was minimal. In the middle of the growing season, for which the sufficiency ranges were set, leaf P concentrations tended to approach the lower limit of the sufficiency range (Fig. 7). Leaf K concentrations were also particularly high in 2016. Leaf
$\mathrm{K}$ concentrations were found centered in the sufficiency range but the values were widely spread below and above the limits of the sufficiency range. Leaf Ca concentrations showed no sensitivity to crop load but, as leaf $\mathrm{K}$ concentrations, they fluctuated widely to above and below the adequate sufficiency range established for the nutrient. Leaf $\mathrm{Mg}$ concentrations did not show relevant oscillations throughout the growing season and in different years and generally were found within the sufficiency range. The concentrations of $\mathrm{Fe}$ in the leaves showed an increasing trend throughout the growing season and in some samplings the values were found above the upper limit of the sufficiency range. Leaf Mn concentrations displayed a similar pattern throughout the different sampling dates and years but the values fell substantially above the upper limit of the sufficiency range. Leaf $\mathrm{Cu}$ concentrations generally remained within the sufficiency range, with the higher values recorded in the first sampling date of 2016. Leaf $\mathrm{Zn}$ concentrations showed a downward trend throughout the growing season and values often exceeded the upper limit of the sufficiency range.

The concentration of $\mathrm{N}$ in the kernel showed an increasing trend with the application of $\mathrm{N}$ to the soil, but the results did not have statistical significance (Fig. 8). However, the differences between years were clear, with kernel $\mathrm{N}$ concentration being higher in 2016 and lower in 2015. $\mathrm{N}$ applied as a foliar spray had no significant effect on kernel $\mathrm{N}$ concentration (data not shown). $\mathrm{N}$ applied to the soil significantly increased shell N concentration in 2015 and 2017 (in 2016 some plots did not produce enough fruit for analysis). However, the concentration of $\mathrm{N}$ in the shell was very low (1.0 to $2.9 \mathrm{~g} \mathrm{~kg}^{-1}$ ) compared to $\mathrm{N}$ concentration in the kernel (27.5 to $45.2 \mathrm{~g} \mathrm{~kg}^{-1}$ ). The concentration of $\mathrm{N}$ in the hull also increased significantly with the $\mathrm{N}$ applied to the soil in the two years in which the plant material was analyzed. The values of $\mathrm{N}$ in this tissue were also low (2.8 to $8.9 \mathrm{~g} \mathrm{~kg}^{-1}$ ) compared to the concentration of $\mathrm{N}$ in the kernel but higher than the concentration of $\mathrm{N}$ in the shell. The concentration of $\mathrm{N}$ in the flowers did not significantly vary with $\mathrm{N}$ applied to the soil. However, the flowers of 2016 showed higher $\mathrm{N}$ concentrations than the flowers of 2017. Flowers are tissues relatively highly concentrated in $\mathrm{N}$, only surpassed by the leaves. Foliar applied $\mathrm{N}$ had no significant effect on tissue $\mathrm{N}$ concentrations (data not shown).

The application of $\mathrm{B}$ to the soil significantly increased the concentration of $B$ in the kernel in two of the three years in which the tissue was analyzed (Fig. 9). The average kernel B concentration ranged from 14.8 to $24.3 \mathrm{mg} \mathrm{kg}^{-1}$. Shell B concentration showed an increasing trend with the application of B to the soil, although only in 2015 the differences were statistically significant. B concentrations in this tissue ranged from 7.5 to $18.4 \mathrm{mg} \mathrm{kg}^{-1}$. The concentration of $B$ in the hull increased significantly with $B$ rate. Mean values were found in the range of 23.0 to $69.6 \mathrm{mg} \mathrm{kg}^{-1}$, which means that the hull is the most concentrated $\mathrm{B}$ tissue of the almond fruit. The concentration of $\mathrm{B}$ in flowers also increased significantly with the application of B to the soil in 2016, with mean values varying between 22.4 and $48.3 \mathrm{mg} \mathrm{kg}^{-1}$. The application of B as a foliar spray did not significantly increase B concentration in any of the different tissues analyzed (data not shown).

\subsection{Nutrient removal in the fruit}

The average $\mathrm{N}$ removal in the crop in the two most productive years (2015 and 2017) was $44.8 \mathrm{~kg} \mathrm{hm}^{-2}$, distributed by kernel $(25.5 \mathrm{~kg}$ ), shell (4.8 kg) and hull (14.5 kg) (Table 2). Per Mg of fruit, $\mathrm{N}$ removal reached $8.5 \mathrm{~kg}$. B removal accounted for $121.1 \mathrm{~g} \mathrm{hm}^{-2}$, hull $(75.1 \mathrm{~g})$ and kernel (11.6 g) being, respectively, the most and least important tissues. Per $\mathrm{Mg}$ of fruit, B removed was $31.3 \mathrm{~g}$. In the case of $\mathrm{P}, 3.6 \mathrm{~kg}$ $\mathrm{hm}^{-2}$ was removed, mainly in the kernel $(2.7 \mathrm{~kg})$, which accounted for $0.8 \mathrm{~kg} \mathrm{P} \mathrm{Mg}{ }^{-1}$ fruit. $\mathrm{K}$ was the nutrient removed in higher amount, $47.8 \mathrm{~kg} \mathrm{hm}^{-2}$, with the hull $(32.7 \mathrm{~kg}$ ) being the most important tissue. $\mathrm{K}$ removal in fruit represented $10.6 \mathrm{~kg} \mathrm{Mg}^{-1}$ fruit. $\mathrm{Ca}$ and $\mathrm{Mg}$ were respectively removed in amounts of 1.2 and $0.8 \mathrm{~kg} \mathrm{Mg}^{-1}$ fruit. The micronutrients $\mathrm{Fe}, \mathrm{Mn}, \mathrm{Cu}$ and $\mathrm{Zn}$ were removed respectively in the 

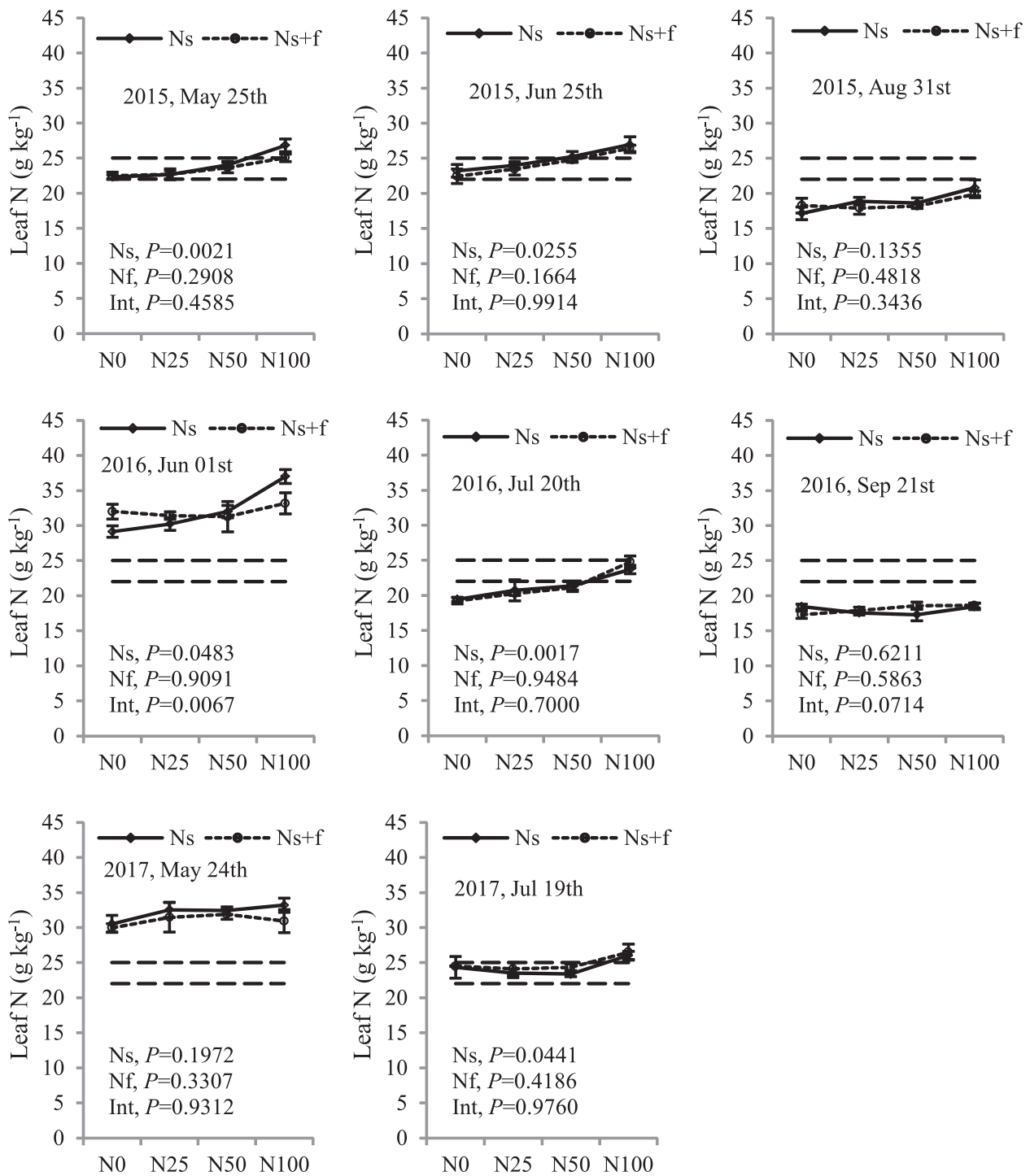

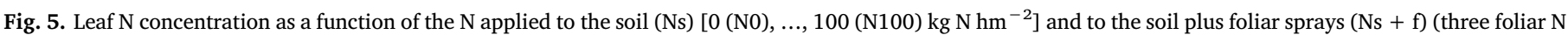

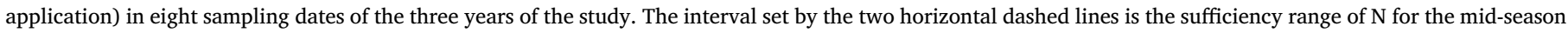

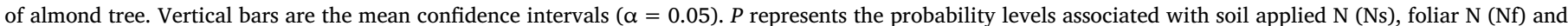
interaction (Int) between the two variables in a split plot design where Ns was assigned to the main plots and Nf to subplots.

amounts of 74.6, 27.0, 6.5, and $20.5 \mathrm{~g} \mathrm{Mg}^{-1}$ fruit.

\section{Discussion}

The application of $\mathrm{N}$ to the soil resulted in a consistent increase in production with significant differences among treatments in 2015 and in the accumulated kernel yield of the three years of the study. $\mathrm{N}$ is an important ecological factor limiting crop productivity in most agricultural ecosystems, and its application as a fertilizer tends to result in increased production. Previous studies on almond, although under very different management conditions, have also shown an increase in crop productivity due to the application of $\mathrm{N}$ to the soil (Muhammad et al., 2015; Zarate-Valdez et al., 2015). Foliar application of nutrients to crops has also been seen as an alternative or a complement to soil application (Eicher and Fernández, 2012; Havlin et al., 2014). However, in this study, foliar application of $\mathrm{N}$ failed to increase kernel yield or even leaf $\mathrm{N}$ concentration.

The application of B to the soil, or as a foliar spray, did not significantly increase kernel yield. A previous study in almond had emphasized the importance of post-harvest leaf $\mathrm{B}$ applications in increasing tissue B concentration, return bloom and yield (Nyomara et al.,
1999). This result was not corroborated by our data, although the application of $B$ to the soil has contributed to a significant increase in the concentration of B in leaves. However, B deficiency is a nutritional disorder widespread in the region among dicots (Arrobas et al., 2010, 2017; 2018; Rodrigues et al., 2011) and in several other parts of the world (Shorrocks, 1997; Fageria et al., 2002). In situations of deficiency, B can negatively affect plant growth and yield, as it plays a central role in the formation and functioning of the cell wall and can affect several metabolic pathways, such as amino acid and protein metabolism and the regulation of the supply of auxins and polyphenols (Broadley et al., 2012). The initial B level in the soil (Table 1) allow it to be classified as high (LQARS, 2006), in contrast to that is most common in the region, and may justify the lack of response to the application of the nutrient as a fertilizer. It should also be noted that in some leaf samples, B concentration was found to be below the sufficiency range currently established for this crop (Bryson et al., 2014), which should have produced a positive response to the application of the nutrient. Alternatively, this result may mean that the lower limit of the sufficiency range is set at a very high value, far from the level of deficiency, at least for rainfed managed orchards.

The concentrations of nutrients in the leaves throughout the 

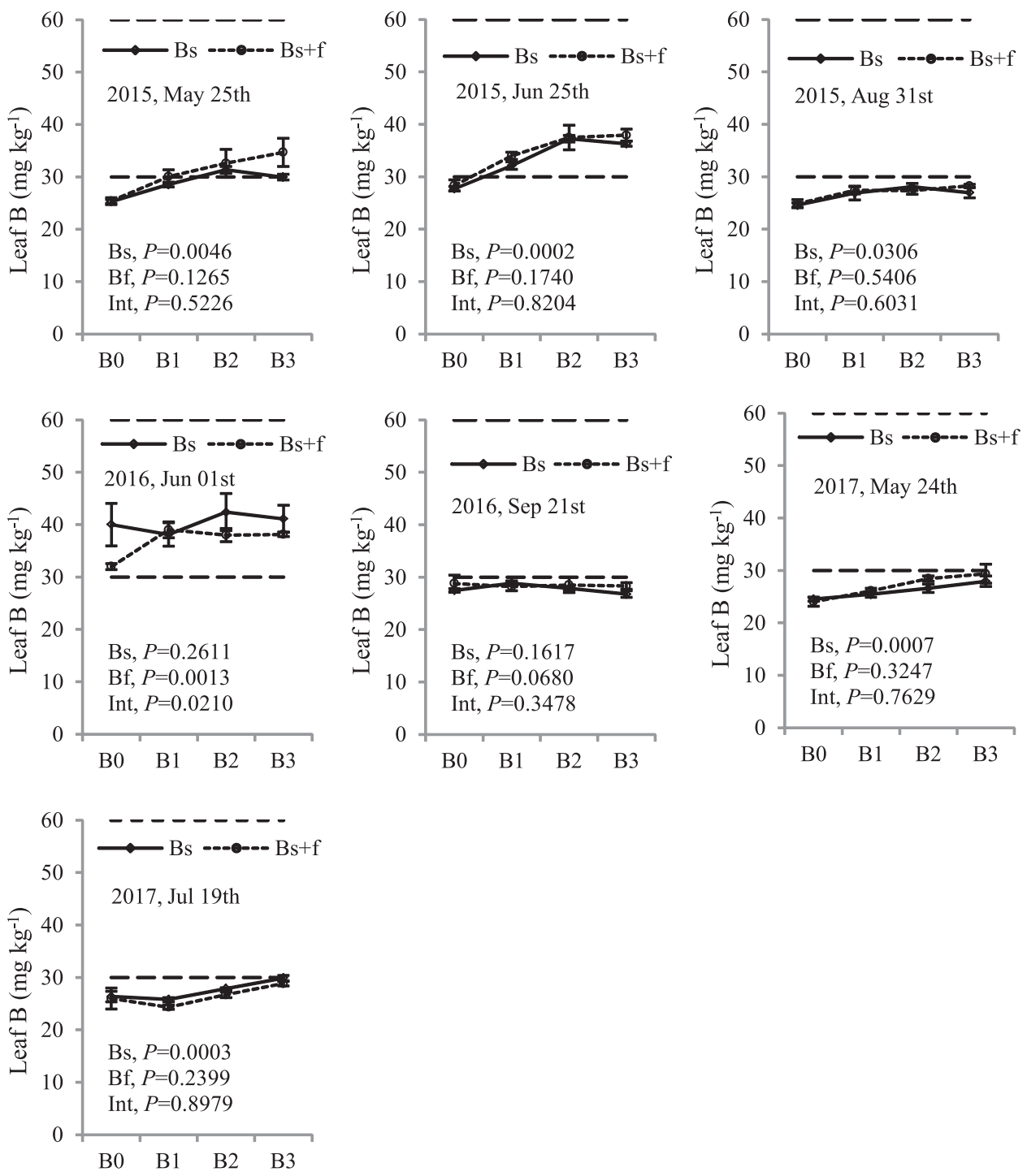

Fig. 6. Leaf B concentration as a function of the B applied to the soil (Bs) $\left[0\right.$ (B0), .., 3 (B3) $\mathrm{kg} \mathrm{B} \mathrm{hm}^{-2}$ ] and to the soil plus foliar sprays (Bs $+\mathrm{f}$ ) (two foliar B applications) in seven sampling dates of the three years of the study. The interval set by the two horizontal dashed lines is the sufficiency range of $B$ for the midseason of almond tree. Vertical bars are the mean confidence intervals $(\alpha=0.05)$. P represents the probability levels associated with soil applied B (Bs), foliar B (Bf) and interaction (Int) between the two variables in a split plot design where Bs was assigned to the main plots and Bf to subplots.

growing season and their comparison with the respective sufficiency ranges provide some considerations regarding the interpretation of plant analysis results. Some nutrients showed significant variations during the growing season. $\mathrm{N}$ decreased markedly, with $\mathrm{P}, \mathrm{Cu}$ and $\mathrm{Zn}$ also showing some tendency to decrease. Conversely, leaf Fe concentration tended to increase. These temporal fluctuations in leaf nutrient concentrations are related to the mobility of the nutrients in plant tissues and their remobilization during the aging process (White, 2012). In practice, this means that the standardized sampling dates for which the sufficiency ranges were established must be scrupulously followed, which is a limitation of using leaf analysis as a diagnostic tool in fertilizer recommendation systems. The problem is common in other crops and has triggered a research effort to develop systems of results' interpretation that allow sampling at any time during the growing season (Scharf, 2001; Rodrigues, 2004; Rodrigues et al., 2005; Saa et al., 2014). Unfortunately, in the case of almond tree, these tools are not fully developed, and leaf sampling is recommended for mid-season (Bryson et al., 2014), which corresponds to July and early August in the Northern hemisphere.

The application of $\mathrm{N}$ to the soil significantly increased the concentration of $\mathrm{N}$ in shell and hull and revealed an increasing trend without significant differences in kernel and flowers. Kernel and flowers showed higher concentrations of $\mathrm{N}$ in the 'off' year, probably due to reduced sink size which gave rise to a phenomenon of nutrient concentration, which is well-known from early studies on plant analysis (Smith, 1962; Jarrel and Beverley, 1981). In contrast, foliar application of $\mathrm{N}$ did not increase $\mathrm{N}$ concentration in those plant tissues. Tissue $\mathrm{B}$ concentration as a response to soil or foliar $\mathrm{B}$ followed a trend similar to that recorded for N. However, while the concentration of $\mathrm{N}$ varied greatly between tissues, B concentration revealed values of similar order of magnitude in all tissues, although hull and flowers tended to have higher B concentrations. The presence of B in high amounts in all tissues is probably due to the fact that in higher plants a significant fraction of the total B is complexed as cis-diol esters in cell walls associated with cell wall pectins (Power and Woods, 1997: Blevins and Lukaszewski, 1998; Broadley et al., 2012), B thus being an important constituent of all plant tissues.

For other nutrients, such as $\mathrm{P}, \mathrm{K}$ and $\mathrm{Cu}$, leaf concentrations were substantially higher in the 'off' year, especially at the beginning of the growing season. The phenomenon can be related to a concentration effect and source/sink size relationship, and has been observed in other crops (Sibbett and Ferguson, 2002; Bustan et al., 2013). Several 

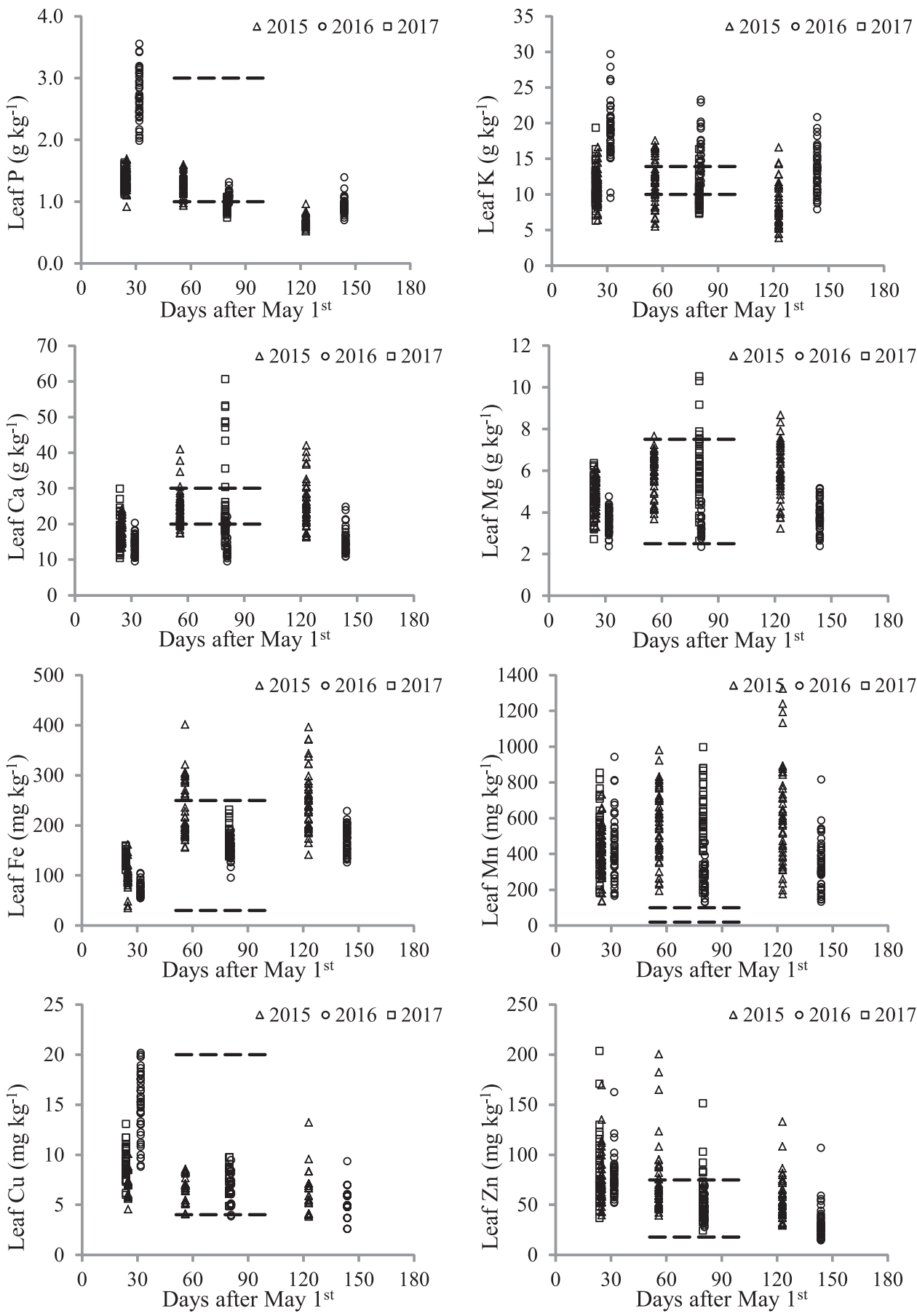

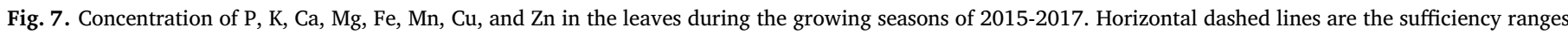
established for the crop at mid-season after Bryson et al. (2014).

nutrients systematically fell outside their sufficiency ranges even for the samplings performed within the interval set for the standard procedure. The sufficiency ranges appeared to be too narrow for $\mathrm{N}$ (22 to $25 \mathrm{~g}$ $\left.\mathrm{kg}^{-1}\right), \mathrm{K}\left(10\right.$ to $\left.15 \mathrm{~g} \mathrm{~kg}^{-1}\right)$ and $\mathrm{Ca}\left(20\right.$ to $\left.30 \mathrm{~g} \mathrm{~kg}^{-1}\right)$, given the large number of values that fell out of the respective sufficiency range. The problem appears to be particularly striking for $\mathrm{K}$ and $\mathrm{Ca}$, given that actual values varied between 5 to $30 \mathrm{~g} \mathrm{~kg}^{-1}$ and 9 to $60 \mathrm{~g} \mathrm{~kg}^{-1}$ respectively, this variation being recorded in a simple experiment in the same soil and where $\mathrm{K}$ and $\mathrm{Ca}$ were not factors of variation in the experimental design. In the cases of $\mathrm{Fe}, \mathrm{Zn}$ and above all $\mathrm{Mn}$, it seems that the upper limit of the sufficiency range can be increased significantly. In the case of $\mathrm{Mn}$, the sufficiency range is set at 20 to $100 \mathrm{mg} \mathrm{kg}^{-1}$, whereas actual leaf $\mathrm{Mn}$ concentrations were recorded between 100 and
$1400 \mathrm{mg} \mathrm{kg}^{-1}$. Such high values should be due to the acidic nature of the soil, which is one of the factors that may lead to an increase in the solubility of Mn (George et al., 2012). However, it seems clear that the upper limit of the sufficiency range $\left(100 \mathrm{mg} \mathrm{kg}^{-1}\right)$ can significantly increase without risk of toxicity to plants as seen in this study. Taken together, these results reveal that sufficiency ranges may have been devised with little reference to experimental data and perhaps based on hardly any data from rainfed managed orchards.

The average removal of nutrients per $\mathrm{Mg}$ of fruit (kernel, shell and hull) reached 8.5, 0.8, 10.6, 1.2 and $0.8 \mathrm{~kg}$, respectively of $\mathrm{N}, \mathrm{P}, \mathrm{K}, \mathrm{Ca}$ and $\mathrm{Mg}$ and $31.3 \mathrm{~g}$ of $\mathrm{B}$. Total removals of $\mathrm{N}, \mathrm{P}$ and $\mathrm{K}$, the macronutrients usually included in the fertilization programs, based on the crops of 2015 and 2017, reached average values of 44.8, 3.6 and 

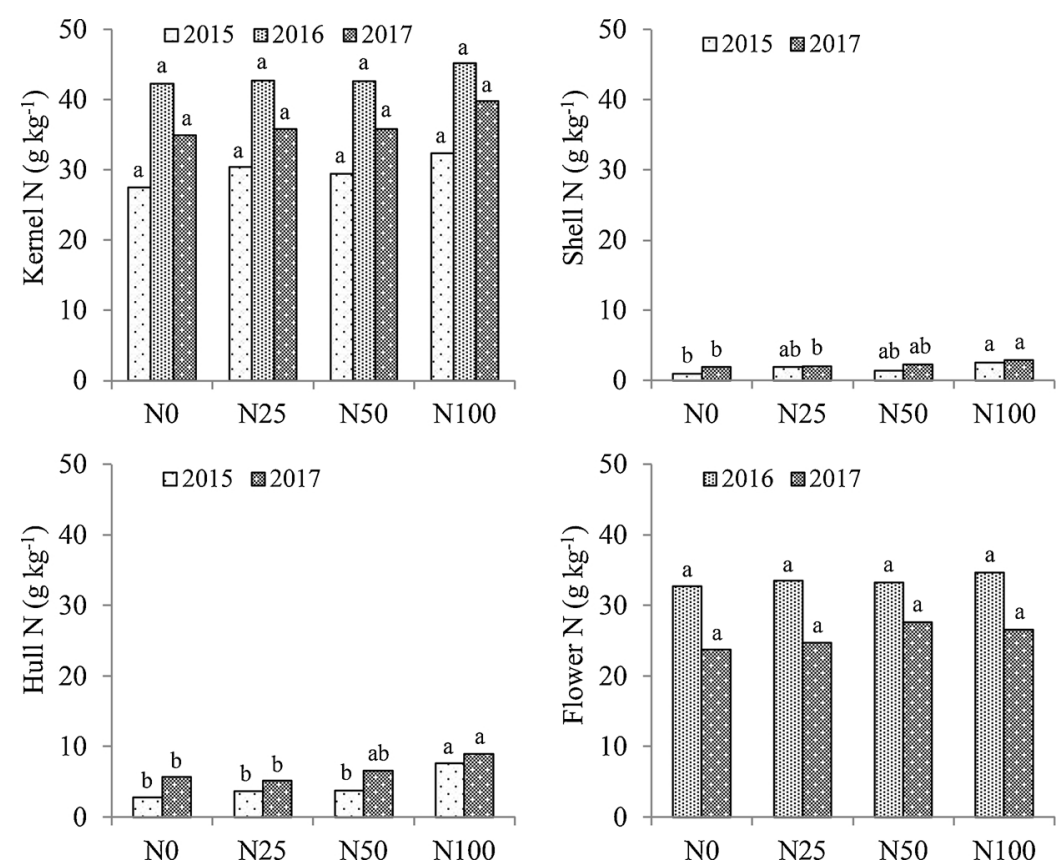

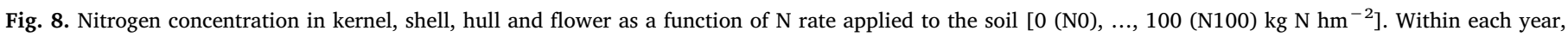
means followed by the same letter are not significantly different by Tukey HSD test $(\alpha=0.05)$.

$47.8 \mathrm{~kg} \mathrm{hm}^{-2}$, respectively, and the amount of B removed was $112.1 \mathrm{~g}$ $\mathrm{hm}^{-2}$. Muhammad et al. (2015) estimated macronutrient removals several times higher (5-10, depending on the nutrient) in an irrigated field trial in California in which almond yield was approximately four times higher and where substantially more fertilizers were applied, in particular $\mathrm{N}\left(391 \mathrm{~kg} \mathrm{hm}^{-2}\right.$ vs $100 \mathrm{~kg} \mathrm{hm}^{-2}$ in the most fertilized plots in this study). The results here reported for $\mathrm{N}, \mathrm{P}$ and $\mathrm{K}$ (8.7, 0.8 and $10.6 \mathrm{~kg} \mathrm{Mg}^{-1}$ fruit) are close to those reported by Arquero and Serrano (2013) (10-20, 0.7-1.1, 10.8-12.4 $\mathrm{kg} \mathrm{Mg}^{-1}$ fruit), in a manual devoted to the almond tree, in which the only relevant difference is $\mathrm{N}$. Our conservative fertilization strategy, using only $100 \mathrm{~kg} \mathrm{~N} \mathrm{hm}^{-2}$ as the maximum $\mathrm{N}$ rate, in addition to aspects related to cultivars, may justify the differences found in $\mathrm{N}$ removal. This result draws attention to the need of adjusting the fertilizer rates to crop needs, particularly in rainfed conditions, in order to increase the farmer's profit and reduce environmental contamination. In this study, almond yield did not significantly increase for $\mathrm{N}$ rates higher than $25 \mathrm{~kg} \mathrm{hm}^{-2}$ if the accumulated almond yield of the three years were taken into account. On the other hand, the plant removed less than $10 \mathrm{~kg} \mathrm{~N} \mathrm{hm}^{-2}$ per $\mathrm{Mg}$ of fruit, which recommends the use of very moderate rates of $\mathrm{N}$ in these orchards.

A noteworthy result of this work was also the profound alternatefruiting pattern observed, which gave rise to two years (2015 and 2017) of satisfactory crops, taking into account that the orchard is rainfed
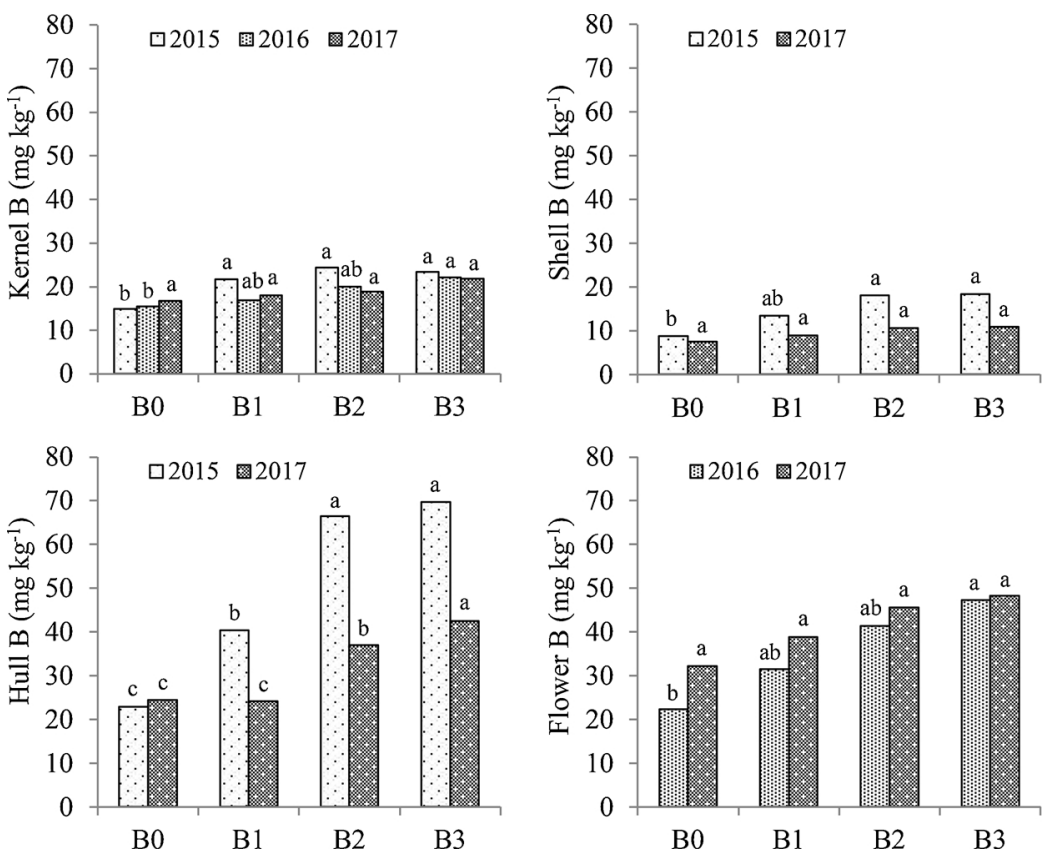

Fig. 9. Boron concentration in kernel, shell, hull and flower as a function of B rate applied to the soil $\left[0\right.$ (B0), ..., 3 (B3) $\left.\mathrm{kg} \mathrm{B} \mathrm{hm}^{-2}\right]$. Within each year, means followed by the same letter are not significantly different by Tukey HSD test $(\alpha=0.05)$. 
Table 2

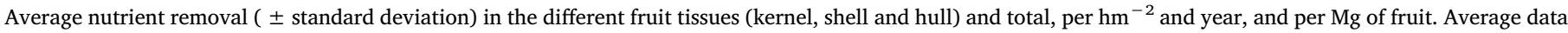
of 2015 and 2017.

\begin{tabular}{|c|c|c|c|c|c|}
\hline \multicolumn{5}{|c|}{ Nutrient removal per $\mathrm{hm}^{-2}$ and year } & \multirow{2}{*}{$\begin{array}{l}\text { Per Mg fruit } \\
\text { Total }\end{array}$} \\
\hline & Kernel & Shell & Hull & Total & \\
\hline${ }^{1} \mathrm{~N}(\mathrm{~kg})$ & $25.5 \pm 7.0$ & $4.8 \pm 2.0$ & $14.5 \pm 4.9$ & $44.8 \pm 12.7$ & $8.5 \pm 1.2$ \\
\hline${ }^{1} \mathrm{~B}(\mathrm{~g})$ & $11.6 \pm 3.5$ & $25.3 \pm 12.4$ & $75.1 \pm 30.5$ & $121.1 \pm 43.9$ & $31.3 \pm 9.6$ \\
\hline${ }^{2} \mathrm{P}(\mathrm{kg})$ & $2.7 \pm 0.9$ & $0.2 \pm 0.1$ & $0.8 \pm 0.4$ & $3.6 \pm 1.2$ & $0.8 \pm 0.1$ \\
\hline${ }^{2} \mathrm{~K}(\mathrm{~kg})$ & $6.2 \pm 2.8$ & $8.9 \pm 6.8$ & $32.7 \pm 12.1$ & $47.8 \pm 18.0$ & $10.6 \pm 1.5$ \\
\hline${ }^{2} \mathrm{Ca}(\mathrm{kg})$ & $1.0 \pm 0.4$ & $2.3 \pm 2.2$ & $2.3 \pm 1.0$ & $5.6 \pm 3.1$ & $1.2 \pm 0.6$ \\
\hline${ }^{2} \mathrm{Mg}(\mathrm{kg})$ & $1.5 \pm 0.5$ & $0.8 \pm 0.4$ & $1.6 \pm 0.6$ & $3.8 \pm 1.4$ & $0.8 \pm 0.1$ \\
\hline${ }^{2} \mathrm{Fe}(\mathrm{g})$ & $25.1 \pm 9.0$ & $60.0 \pm 66.3$ & $252.3 \pm 198.4$ & $337.4 \pm 252.3$ & $74.6 \pm 45.2$ \\
\hline${ }^{2} \mathrm{Mn}(\mathrm{g})$ & $19.1 \pm 9.9$ & $43.0 \pm 26.8$ & $57.8 \pm 27.9$ & $119.8 \pm 58.2$ & $27.0 \pm 9.1$ \\
\hline${ }^{2} \mathrm{Cu}(\mathrm{g})$ & $8.9 \pm 3.6$ & $10.4 \pm 5.3$ & $9.5 \pm 4.4$ & $28.9 \pm 11.0$ & $6.5 \pm 1.2$ \\
\hline${ }^{2} \mathrm{Zn}(\mathrm{g})$ & $35.3 \pm 14.3$ & $26.7 \pm 14.1$ & $29.9 \pm 14.1$ & $91.9 \pm 35.9$ & $20.5 \pm 3.9$ \\
\hline
\end{tabular}

1 Based on the fertilized treatments N100 and NF3 and B3 and BF2, respectively for N and B.

2 Based on all tissue analyses.

managed, interspersed with a year (2016) in which the production was practically nil. Alternate-bearing is a well-known phenomenon in Mediterranean fruticulture and is mainly associated with the competition for resources between the crop of a given year and the development of the reproductive structures which ensure production in the following year (Rallo and Suarez, 1989; Cuevas et al., 1995; Rodrigues and Arrobas, 2010). In general, after a good crop ('on' year) a lighter one ('off' year) usually follows and vice versa. The effect tends to be more pronounced when growing conditions are poor (Lavee et al., 1983; Sibbett and Ferguson, 2002; Rodrigues and Arrobas, 2010). The farmer reported that the phenomenon has been often recorded but is not usually as severe, with years of production as low as 2016 being rare. An unfavourable combination of events may have led to the failure of 2016 production: firstly, the fact that production had been high in 2015, which may have reduced the potential of fruiting expected in 2016 due to the alternate-bearing habit of almond; secondly, in January 2016, the farmer performed a more severe pruning, that usually occurs every three years, which will have reduced the number of flowers the following year; thirdly, and probably decisive, during blossom of 2016 the weather was characterized by persistent rain (Fig. 2), which may have washed away valuable pollen and hindered the flight of pollinating insects, important factors for self-incompatible varieties (Aguiar, 2017) such are these.

\section{Conclusions}

Leaf sprays of $\mathrm{N}$ and $\mathrm{B}$, including post-harvest applications, failed to increase crop nutritional status and kernel yield. In these low-input farming systems, the application of fertilizers to the soil seems to be simpler and a more effective way of managing the nutritional status of the orchard. To use the currently established sufficiency ranges, sampling at mid-season should be carried out given the fluctuation of some nutrients throughout the growing season. The sufficiency ranges established after Bryson et al. (2014) do not seem to be appropriate for most of the nutrients, at least for use in rainfed orchards. The sufficiency ranges for $\mathrm{N}, \mathrm{K}$ and $\mathrm{Ca}$ appear to be excessively narrow, with a high probability of the actual results of plant analysis falling outside the ranges of adequate concentrations without evidence of nutritional imbalance. The lower limit of the sufficiency range established for B appears to be excessively high with no apparent risk of deficiency at lower values. In the cases of $\mathrm{Fe}, \mathrm{Zn}$ and especially $\mathrm{Mn}$, the upper limits of the sufficiency ranges seem to be able to substantially increase without risks of toxicity to plants. Kernel yield did not increase for $\mathrm{N}$ applications above $25 \mathrm{~kg} \mathrm{hm}^{-2}$ and $\mathrm{N}$ removal was less than $10 \mathrm{~kg} \mathrm{Mg}^{-1}$ of fruit. Therefore, in rainfed conditions, it seems to be possible to maintain the productivity at satisfactory levels with moderate applications of $\mathrm{N}$, an important consideration in ensuring economic and ecological sustainability of the production system. The study also showed a marked alternate-bearing phenomenon, a problem that may threaten the sustainability of rainfed managed orchards, although in this case the farmer may have caused it by performing a more severe pruning than recommended.

\section{Acknowledgments}

The authors are grateful to the Foundation for Science and Technology (FCT, Portugal) and FEDER under Programme PT2020 for financial support to CIMO (UID/AGR/00690/2013). The authors also thank Cooperativa Agrícola de Alfândega da Fé for allowing the use of this orchard in the research.

\section{References}

Aguiar, C., 2017. Fenologia, dormência e biologia da reprodução. In: Rodrigues, M.A. (Ed.), Amendoeira, Estado da Produção. Centro Nacional de Competências para os Frutos Secos, Bragança, Portugal, pp. 42-97.

Aguiar, C., Pereira, J.A., 2017. Sistemática, domesticação, morfologia e hábitos de frutificação. In: Rodrigues, M.A. (Ed.), Amendoeira, Estado da Produção. Centro Nacional de Competências para os Frutos Secos, Bragança, Portugal, pp. 1-41.

Almagro, M., de Vente, J., Boix-Fayos, C., García-Franco, N., Melgares de Aguilar, J., González, D., Solé-Benet, A., Martínez-Mena, M., 2016. Sustainable land management practices as providers of several ecosystem services under rainfed Mediterranean agroecosystems. Mitig. Adapt. Strateg. Glob. Change 21, 1029-1043.

Arquero, O., Serrano, N., 2013. Manejo del suelo. In: Arquero, O. (Ed.), Manual del Cultivo del Almendro. Junta de Andalucía, Consejería de Agricultura, Pescas y Desarrollo Rural, Sevilla, España, pp. 47-49.

Arrobas, M., Lopes, J.I., Pavão, F., Cabanas, J.E., Rodrigues, M.A., 2010. Comparative boron nutritional diagnosis for olive based on July and January leaf samplings. Commun. Soil Sci. Plant Anal. 41, 709-720.

Arrobas, M., Afonso, S., Ferreira, I.Q., Moutinho-Pereira, J.M., Correia, C.M., Rodrigues, M.A., 2017. Liming and application of nitrogen, phosphorus, potassium and boron on a young plantation of chestnut. Turk. J. Agric. For. 41, 441-451.

Arrobas, M., Afonso, S., Rodrigues, M.A., 2018. Diagnosing the nutritional condition of chestnut groves by soil and leaf analyses. Sci. Hortic. 228, 113-121.

Blevins, D.G., Lukaszewski, K.M., 1998. Boron in plant structure and function. Annu. Rev. Plant Physiol. Plant Mol. Biol. 49, 481-500.

Broadley, M., Brown, P., Cakmak, I., Rengel, Z., Zhao, F., 2012. Function of nutrients: micronutrients. In: Marshner, P. (Ed.), Marschner'S Mineral Nutrition of Higher Plants. Elsevier, pp. 191-248.

Bryson, G., Mills, H.A., Sasseville, D.N., Jones Jr, J.B., Barker, A.V., 2014. Plant Analysis Handbook III. A Guide to Sampling, Preparation, Analysis and Interpretation for Agronomic and Horticultural Crops. Micro-Macro Publishing, Inc.

Bustan, A., Avni, A., Yermiyahua, V., Ben-Gal, A., Riov, J., Erel, R., Zipori, I., Dag, A., 2013. Interactions between fruit load and macroelement concentrations in fertigated olive (Olea europea L.) trees under arid saline conditions. Sci. Hortic. 152, 44-55.

Cuevas, J., Rapoport, H.F., Rallo, L., 1995. Relationship among reproductive processes and fruitless abscission in 'Arbequina' olive. Adv. Hortic. Sci. 9, 92-96.

EC (European Commission), 2010. Europe 2020: a European Strategy for Smart, Sustainable and Inclusive Growth. European Commission.

Eicher, T., Fernández, V., 2012. Uptake and release of elements by leaves and other aerial plant parts. In: Marshner, P. (Ed.), Marschner'S Mineral Nutrition of Higher Plants. Elsevier, pp. 71-84.

Fageria, N.K., Baligar, V.C., Clark, R.B., 2002. Micronutrients in crop production. Adv. Agron. 77, 185-268. 
FAO (Food and Agriculture Organization of the United Nations), 2018. Crops. Accessed October 2018. http://www.fao.org/faostat/en/\#data/QC.

George, E., Horst, W.J., Neumann, E., 2012. Adaptation of plants to adverse chemical soil conditions. In: Marshner, P. (Ed.), Marschner's Mineral Nutrition of Higher Plants. Elsevier, pp. 409-437.

Günes, N.T., Okay, Y., Köksal, A.I., Köroğlu, M., 2010. The effect of nitrogen and phosphorus fertilization on yield, some fruit characteristics, hormone concentrations, and alternate bearing in pistachio. Turk. J. Agric. For. 34, 33-43.

Havlin, J.L., Tisdale, S.L., Nelson, W.L., Beaton, J.D., 2014. Soil Fertility and Fertilizers. An Introduction to Nutrient Management. Pearson, Inc.

Jarrel, W.M., Beverley, R.B., 1981. The dilution effect in plant nutrition studies. Adv. Agron. 34, 197-224.

Lavee, S., Haskal, A., Bem-Tal, Y., 1983. Girdling olive trees, a partial solution to biennial bearing. I. Methods, timing and direct tree response. J. Am. Soc. Hortic. Sci. 58, 209-218.

LQARS (Laboratório Químico Agricola Rebelo da Silva), 2006. Manual de Fertilização das culturas. Instituto Nacional de Investigação Agrária, Lisboa, Portugal.

Muhammad, S., Sanden, B.L., Lampinen, B.D., Saa, S., Siddiqui, M.I., Smart, D.R., Olivos, A., Shackel, K.A., DeJong, T., Brown, P.H., 2015. Seasonal changes in nutrient content and concentrations in a mature deciduous tree species: Studies in almond (Prunus dulcis (Mill.) D. A. Webb). Eur. J. Agron. 65, 52-68.

Nyomora, A.M.S., Brown, P.H., 1999. Rate and time of boron application increase almond productivity and tissue boron concentration. Hortsci. 34, 242-245.

Power, P.P., Woods, W.G., 1997. The chemistry of boron and its speciation in plants. Plant Soil 193, 1-13.

Rallo, L., Suarez, M.P., 1989. Seasonal distribution of dry matter within the olive fruitbearing limb. Adv. Hortic. Sci. 3, 55-59.

Rodrigues, M.A., 2004. Establishment of continuous critical levels for indices of plant and pre sidedress soil N status in the potato crop. Commun. Soil Sci. Plant Anal. 35, 2067-2085.

Rodrigues, M.A., Arrobas, M., 2010. Analysis of yearly variation on olive yields and its relation to alternate fruiting. 6th International Conference on Simulation and Modelling in the Food and Bio-Industry 2010 202-205.

Rodrigues, M.A., Coutinho, J., Martins, J., Arrobas, M., 2005. Quantitative sidedress nitrogen recommendations for potatoes based upon crop nutritional indices. Eur. J. Agron. 23, 79-88.
Rodrigues, M.A., Pavão, F., Lopes, J.I., Gomes, V., Arrobas, M., Moutinho-Pereira, J., Ruivo, S., Cabanas, J.E., Correia, C.M., 2011. Olive yields and tree nutritional status during a four year period without nitrogen and boron fertilization. Commun. Soil Sci. Plant Anal. 42, 803-814.

Saa, S., Brown, P.H., Muhammad, S., Olivos-Del Rio, A., Sanden, B.L., Laca, E.A., 2014 Prediction of leaf nitrogen from early season samples and development of field sampling protocols for nitrogen management in Almond (Prunus dulcis [Mill.] DAWebb). Plant Soil 380, 153-163.

Saa, S., Peach-Fine, E., Brown, P., Michailides, T., Castro, S., Bostock, R., Laca, E., 2016. Nitrogen increases hull rot and interferes with the hull split phenology in almond (Prunus dulcis). Sci. Hortic. 199, 41-48.

Saa, S., Fernández, E., Muhammad, S., Olivos-Del Rio, A., DeJong, T.M., Laca, E., Brown, P., 2017. Increases in leaf nitrogen concentration and leaf area did not enhance spur survival and return bloom in almonds (Prunus dulcis [Mill.] DA Webb). Acta Physiol. Plant. 39, 107.

Scharf, P.C., 2001. Soil and plant tests to predict optimum nitrogen rates for corn. J. Plant Nutr. 24, 805-826.

Shorrocks, U.M., 1997. The occurrence and correction of boron deficiency. Plant Soil 193, $121-148$.

Sibbett, G.S., Ferguson, L., 2002. Nitrogen, boron, and potassium dynamic in "on" vs "off" cropped Manzanillo olive trees in California, USA. Acta Hortic. 586, 369-373.

Smith, P.F., 1962. Mineral analysis of plant tissues. Ann. Rev. Plant Physiol. 13, 81-108.

Weinbaum, S.A., Picchioni1, G.A., Muraoka, T.T., Ferguson, L., Brown, P.H., 1994. Fertilizer nitrogen and boron uptake, storage, and allocation vary during the alternate-bearing cycle in pistachio trees. J. Am. Soc. Hortic. Sci. 119, 24-31.

Werner, W., 2007. Nitrogen (chapter 9). Ullmann's Agrochemicals. Fertilizers, vol. 3 Wiley-VCH Verlag GmbH \& Co. KGaA, Weinheim.

White, P.J., 2012. Long-distance transport in the xylem and phloem. In: Marshner, P. (Ed.), Marschner's Mineral Nutrition of Higher Plants. Elsevier, pp. 49-70.

WRB, 2015. World Reference Base for Soil Resources 2014, Update 2015. International Soil Classification System for Naming Soils and Creating Legends for Soil Maps. World Soil Resources Reports No. 106. FAO, Rome.

Zarate-Valdez, J.L., Muhammad, S., Saa, S., Lampinen, B.D., Brown, P.H., 2015. Light interception, leaf nitrogen and yield prediction in almonds: a case study. Eur. J. Agron. 66, 1-7. 